Article

\title{
Structures of Two New Flavonoids and Effects of Licorice Phenolics on Vancomycin-Resistant Enterococcus Species
}

\author{
Eerdunbayaer $^{1}$, Mohamed A. A. Orabi ${ }^{1,2}$, Hiroe Aoyama ${ }^{1}$, Teruo Kuroda ${ }^{3}$ and \\ Tsutomu Hatano ${ }^{1, *}$
}

1 Department of Natural Product Chemistry, Okayama University, Graduate School of Medicine, Dentistry and Pharmaceutical Sciences, Tsushima-naka, Kita-ku, Okayama 700-8530, Japan; E-Mails: eerdun3@163.com (E.); m_a_orabi@yahoo.com (M.A.A.O.); ph20101@s.okayama-u.ac.jp (H.A.)

2 Faculty of Pharmacy, Al-Azhar University, Assiut 71524, Egypt

3 Drug Discovery Technology Center, Okayama University Graduate School of Medicine, Dentistry and Pharmaceutical Sciences, Tsushima-naka, Kita-ku, Okayama 700-8530, Japan; E-Mail: tkuroda@cc.okayama-u.ac.jp

* Author to whom correspondence should be addressed; E-Mail: hatano@pharm.okayama-u.ac.jp; Tel.: +81-86-251-7936; Fax: +81-86-251-7926.

Received: 28 February 2014; in revised form: 17 March 2014 / Accepted: 21 March 2014 / Published: 28 March 2014

\begin{abstract}
Since our previous study revealed that several licorice phenolics have antibacterial effects on methicillin-resistant Staphylococcus aureus (MRSA), and suppressive effects on the oxacillin resistance of MRSA, we further investigated effectiveness of licorice constituents on vancomycin-resistant Enterococcus (VRE) bacteria, and purified 32 phenolic compounds. Two flavonoids among them were characterized structurally, and identified their structures as demethylglycyrol (31) and 5,7-di- $O$-methylluteone (32), respectively. Examination of antibacterial effects of licorice phenolics showed that 3-arylcoumarins such as licoarylcoumarin (9) and glycycoumarin (26), and 2-arylcoumarones such as gancaonin I (17), have moderate to potent antibacterial effects on the VRE strains used in this study.
\end{abstract}

Keywords: licorice; Glycyrrhiza uralensis; phenolics; flavonoid; 3-arylcoumarin; 2-arylcoumarone; VRE; antibacterial effect 


\section{Introduction}

Licorice is one of the most frequently used natural drugs in Asian traditional medicines. It produces various types of phenolic constituents, in addition to glycyrrhizin and related triterpene glycosides. Recently, the biological activities of licorice extracts and ingredients have attracted many researchers, and their effects in the treatment for different human diseases such as cancer, atherosclerosis, gastric ulcers, hepatitis and immunodeficiency have been summarized in some reviews [1-3]. Potential beneficial effects of licorice in common oro-dental diseases were also discussed in a review article [4]. Potent antibacterial activities of licorice phenolics against bacterial strains such as Helicobacter pylori, cariogenic bacterial species, Streptococcus mutans and Streptococcus sobrinus, and periodontopathogenic species, Porphyromonas gingivalis and Prevotella intermedia, were also reported [5-8]. Our previous investigation revealed that several naturally occurring compounds showed potent antibacterial effects on methicillin-resistant Staphylococcus aureus (MRSA) [9-11], and some of the licorice phenolics, such as licoricidin (1), showed suppressing effects on the oxacillin resistance of MRSA [11].

Among drug-resistant bacteria vancomycin-resistant Enterococci (VRE) is a serious menace for patients in hospitals. Just a few drugs such as linezolid show bacteriostatic activity against vancomycin-resistant strains of E. faecium and E. faecalis, and a combination of quinupristin and dalfopristin, which have bactericidal activity against most drug-resistant staphylococci, streptococci, and pneumococci, appears to be bacteriostatic against E. faecium, and is not active against Enterococcus faecalis [12]. Therefore, we have investigated on the effective constituents of licorice (licorice based on Glycyrrhiza uralensis) on VRE, and found that some phenolics among them had potent to moderate antibacterial effects on VRE. Since two compounds among the phenolics isolated from licorice have not yet been characterized, their structures were established in the present study. This paper describes structural evidence of the two compounds and effects of licorice phenolics on VRE. Worthy that antimicrobial activities of extracts of leaves and roots of Glycyrrhiza species were previously studied [13,14] against several bacterial strains including Enterococcus faecalis. Although a paper reported gancaonin I (17) as a compound with the anti-VRE effect [15], our study revealed several pure phenolic compounds from licorice should also be considered as lead compound candidates for new anti-VRE drugs, as shown below.

\section{Results and Discussion}

The licorice phenolics (Figures 1 and 2) were isolated from the ethyl acetate extract in the following way: the extract was subjected to countercurrent distribution with $\mathrm{CHCl}_{3}-\mathrm{CH}_{3} \mathrm{OH}-\mathrm{H}_{2} \mathrm{O}$, and the less polar fractions were respectively chromatographed on silica gel, ODS-gel, and MCI-gel CHP-20P, to give licoricidin (1) [16], allolicoisoflavone B (2) [17], 3'-( $\gamma, \gamma$-dimethylallyl)-kievitone (3) [18], 7-O-methylluteone (4) [19], kaempferol 3-O-methyl ether (5) [20], and kaempferol (6) [21], and fractions containing phenolics. Those fractions were purified by preparative TLC on silica gel or by preparative HPLC to give isolicoflavonol (7) [22], isoglycycoumarin (8) [23], licoarylcoumarin (9) [24], formononetin (10) [25], and 6"-O-acetylliquiritin (11) [26]. On the other hand, the remaining part of the ethyl acetate fraction was directly subjected to column chromatography on ODS-gel, and fractions 
from the column were further purified by column chromatography on MCI-gel CHP-20P, and by preparative HPLC or preparative TLC, to give liquiritin (12) [27], p-hydroxybenzoic acid (13), semilicoisoflavone B (14) [28], glycyrol (15) [29], glycyrin (16) [29], gancaonin I (17) [30], isoglycyrol (18) [31], liquiritigenin (19) [27], gancaonin G (20) [32], 3-(p-hydroxyphenyl)-7methoxycoumarin (21) [33], 6,8-diprenylorobol (22) [34], isoliquiritin (23) [35], 8-( $\gamma, \gamma$-dimethylallyl)wighteone (24) [36], glicoricone (25) [37], glycycoumarin (26) [38], licocoumarone (27) [29], licoricone (28) [39], glyasperin D (29) [40], isoangustone A (30) [41], and two additional compounds temporarily named compounds A (31), and B (32). Since several phenolics from licorice display potent antibacterial effects against methicillin-resistant Staphylococcus aureus (MRSA), and also show suppressing effects on the oxacillin resistance of MRSA, as we have reported previously [11], we have also investigated the effect of these licorice phenolics on VRE.

Figure 1. Chemical structures of compounds 1-13 and 32 isolated from root and stolon of Glycyrrhiza uralensis.

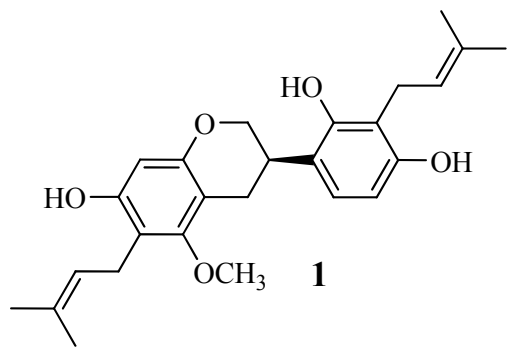<smiles>CC1(C)C=Cc2c(O)ccc(-c3coc4cc(O)cc(O)c4c3=O)c2O1</smiles>

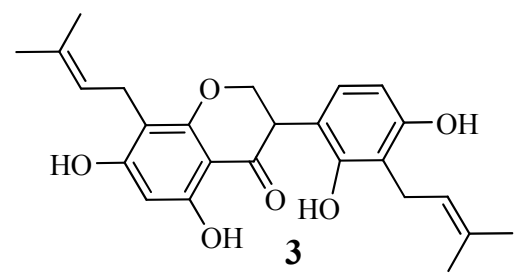<smiles>[R20]c1cc2occ(-c3ccc(O)cc3O)c(=O)c2c([R20])c1CC=C(C)C</smiles>

$4 \quad \mathrm{R}_{1}=\mathrm{H}, \mathrm{R}_{2}=\mathrm{CH}_{3}$ $32 \mathrm{R}_{1}=\mathrm{R}_{2}=\mathrm{CH}_{3}$<smiles>COc1c2c(cc3oc(=O)c(-c4ccc(O)cc4O)cc13)OC(C)(C)CC2</smiles><smiles>[R][R]([R])=C</smiles><smiles>C=CC(C)(C)c1c(O)cc(OC)c2cc(-c3ccc(O)cc3O)c(=O)oc12</smiles><smiles>[R20]C[C@H]1O[C@H](Oc2ccc([C@H]3CC(=O)c4ccc(O)cc4O3)cc2)[C@H](O)[C@@H](O)[C@@H]1O</smiles><smiles>CC(C)=CCc1cc(-c2oc3cc(O)cc(O)c3c(=O)c2O)ccc1O</smiles><smiles>COc1ccc(-c2coc3cc(O)ccc3c2=O)cc1</smiles><smiles>O=C(O)c1ccc(O)cc1</smiles>

13 
Figure 2. Chemical structures of compounds 14-31 isolated from root and stolon of Glycyrrhiza uralensis.
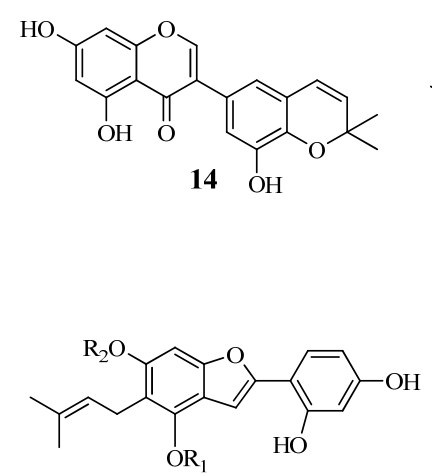

$17 \mathrm{R}_{1}=\mathrm{H}, \mathrm{R}_{2}=\mathrm{CH}_{3}$ $27 \mathrm{R}_{1}=\mathrm{R}_{2}=\mathrm{H}$

20
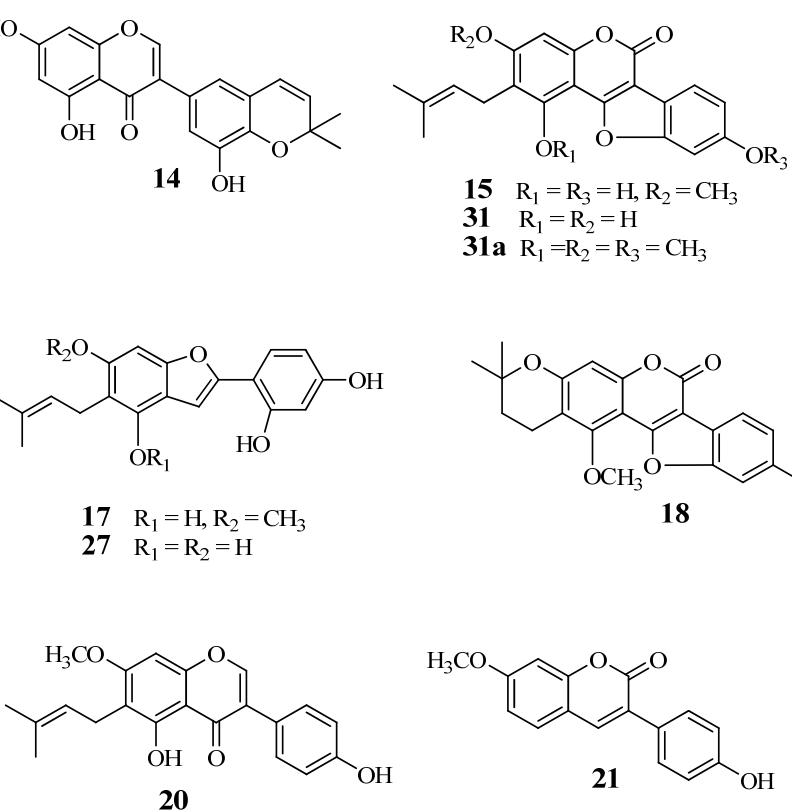

$15 \mathrm{R}_{1}=\mathrm{R}_{3}=\mathrm{H}, \mathrm{R}_{2}=\mathrm{CH}_{3}$

$31 \mathrm{R}_{1}=\mathrm{R}_{2}=\mathrm{H}$

31a $\mathrm{R}_{1}=\mathrm{R}_{2}=\mathrm{R}_{3}=\mathrm{CH}_{3}$

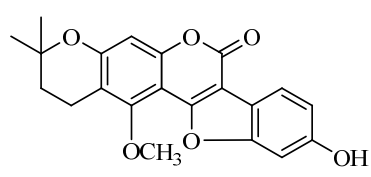

18
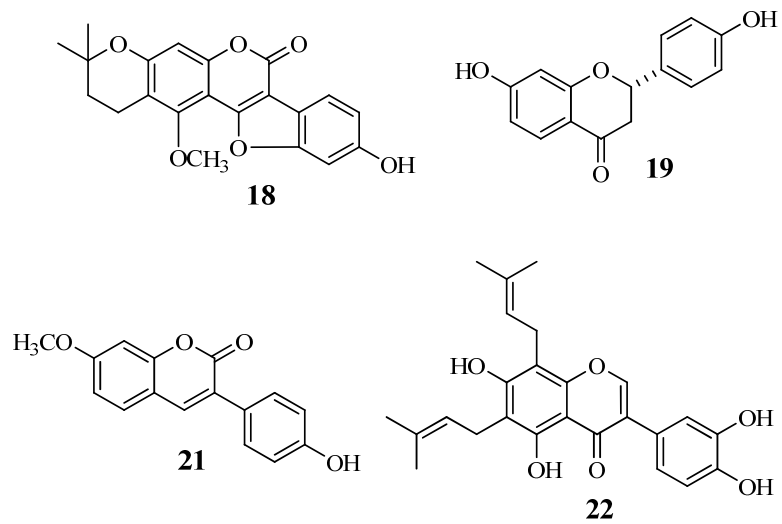

22

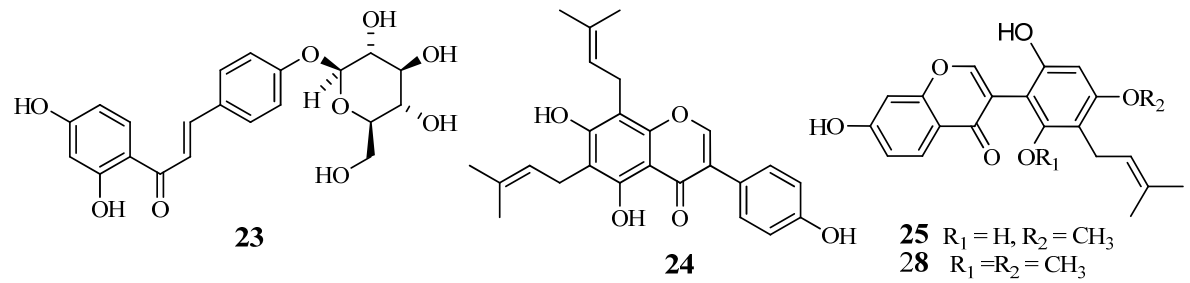<smiles>COc1cc2c(c(OC)c1CC=C(C)C)C[C@@H](c1ccc(O)cc1O)CO2</smiles>

29

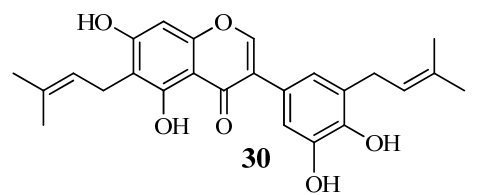

\subsection{Structures of New Compounds}

Compound A (31, Figure 3) was obtained as a pale-yellow microcrystalline powder. The high-resolution fast-atom bombardment mass spectroscopy (HR-FAB-MS) data (found $\mathrm{m} / \mathrm{z} 353.0990$ $[\mathrm{M}+\mathrm{H}]^{+}$, calcd. 353.1025), indicated that this compound has a molecular formula $\mathrm{C}_{20} \mathrm{H}_{16} \mathrm{O}_{6}$. The UV spectrum showed absorption maxima at $259(\log \varepsilon, 4.45)$ and $345 \mathrm{~nm}(\log \varepsilon, 4.23)$, which is similar to glycyrol, suggested that it has a 3-arylcoumarin or related coumestan skeleton as the chromophore. The ${ }^{1} \mathrm{H}-\mathrm{NMR}$ spectrum (Table 1) showed a one-proton singlet at $\delta_{\mathrm{H}} 6.25(\mathrm{H}-4)$ and three protons forming an $\mathrm{ABX}$ system at $\delta_{\mathrm{H}} 6.80(1 \mathrm{H}, \mathrm{d}, J=2.4 \mathrm{~Hz}, \mathrm{H}-10), \delta_{\mathrm{H}} 6.71(1 \mathrm{H}, \mathrm{dd}, J=2.4,8.4 \mathrm{~Hz}, \mathrm{H}-8)$, and $\delta_{\mathrm{H}} 7.25(1 \mathrm{H}, \mathrm{d}, J=8.4 \mathrm{~Hz}, \mathrm{H}-1)$ in the aromatic region, indicating the presence of pentasubstituted and tri-substituted phenyl rings in the molecule. The absence of the H-11a signal (corresponding to $\mathrm{H}-4$ of the 3-arylcoumarin skeleton) indicated the coumestan [29,31] structure for this compound. The remaining signals at $\delta_{\mathrm{H}} 1.60,1.77\left(3 \mathrm{H}\right.$ each, s, dimethyl at $\left.\mathrm{C}-3^{\prime}\right), \delta_{\mathrm{H}} 3.12(2 \mathrm{H}, \mathrm{d}$, $J=6.6 \mathrm{~Hz}$, methylene at $\left.\mathrm{C}-1^{\prime}\right)$, and $\delta_{\mathrm{H}} 5.07(1 \mathrm{H}, \mathrm{t}, J=6.6 \mathrm{~Hz}$, methine at C-2') in the aliphatic proton region are corresponding to the presence of a $\gamma, \gamma$-dimethylallyl (prenyl) group in the molecule. 
The signal pattern in the ${ }^{1} \mathrm{H}-\mathrm{NMR}$ spectrum of $\mathbf{3 1}$ is similar to that of glycyrol (15) except that a methoxyl signal observed in the spectrum of $\mathbf{1 5}$ is absent in that of compound A. Therefore, the structure of demethylglycyrol (31) was assigned for this compound.

Figure 3. HMBC correlations observed for compound A (demethylglycyrol, 31).

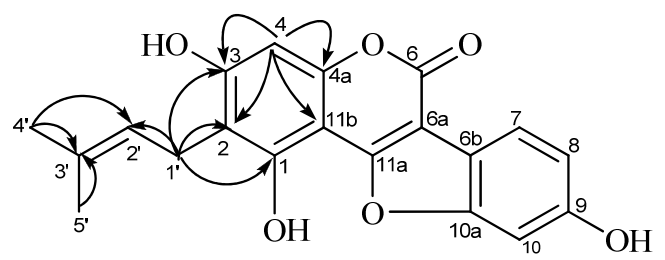

Table 1. $600 \mathrm{MHz}$ NMR Spectroscopic Data for Demethylglycyrol (31) (acetone- $\mathrm{d}_{6}$, $\left.27^{\circ} \mathrm{C}\right)$, and 5,7-Di-O-methylluteone $(32)\left(\mathrm{CD}_{3} \mathrm{OD}, 27^{\circ} \mathrm{C}\right)$.

\begin{tabular}{|c|c|c|c|c|c|c|}
\hline \multirow[b]{2}{*}{ position } & \multicolumn{3}{|c|}{ Demethylglycyrol (31) } & \multicolumn{3}{|c|}{ 5,7-Di- $O$-methylluteone (32) } \\
\hline & $\delta_{\mathrm{C}}$, type & $\delta_{\mathrm{H}}(J$ in $\mathrm{Hz})$ & HMBC $^{a}$ & $\delta_{\mathrm{C}}$, type & $\delta_{\mathrm{H}}(J$ in $\mathrm{Hz})$ & HMBC $^{a}$ \\
\hline $\mathrm{C}-1$ & $160.4, \mathrm{C}$ & & & & & \\
\hline $\mathrm{C}-2$ & $113.9, \mathrm{C}$ & & & $170.1, \mathrm{CH}$ & $7.95, \mathrm{~s}$ & $3,4,1^{\prime}$ \\
\hline $\mathrm{C}-3$ & $158.5, \mathrm{C}$ & & & $119.9, \mathrm{C}$ & & \\
\hline C-4 & $99.4, \mathrm{CH}$ & $6.25, \mathrm{~s}$ & $2,3,4 a, 11 b$ & $178.8, \mathrm{C}$ & & \\
\hline$C-4 a$ & $156.4, \mathrm{C}$ & & & $106.5, \mathrm{C}$ & & \\
\hline $\mathrm{C}-5$ & & & & $159.2, \mathrm{C}$ & & \\
\hline $\mathrm{C}-6$ & $160.1, \mathrm{C}$ & & & $115.6, \mathrm{C}$ & & \\
\hline C-6a & $104.0, \mathrm{C}$ & & & & & \\
\hline$C-6 b$ & $114.9, \mathrm{C}$ & & & & & \\
\hline $\mathrm{C}-7$ & $98.4, \mathrm{CH}$ & $6.80, \mathrm{~d}(2.4)$ & & $160.4, \mathrm{C}$ & & \\
\hline $\mathrm{C}-8$ & $111.9, \mathrm{CH}$ & $6.71, \mathrm{dd}(2.4,8.4)$ & & $96.4, \mathrm{CH}$ & $6.34, \mathrm{~s}$ & $6,7,4 a, 8 a$ \\
\hline C-8a & & & & $156.7, \mathrm{C}$ & & \\
\hline C-9 & $156.6, \mathrm{C}$ & & & & & \\
\hline $\mathrm{C}-10$ & $120.0, \mathrm{CH}$ & $7.25, \mathrm{~d}(8.4)$ & & & & \\
\hline C-10a & 156.1, C & & & & & \\
\hline C-11a & $158.6, \mathrm{C}$ & & & & & \\
\hline$C-11 b$ & 104.1, C & & & & & \\
\hline C-1' & $23.2, \mathrm{CH}_{2}$ & $3.12, \mathrm{~d}(6.6)$ & $1,2,3,2^{\prime}, 3^{\prime}$ & 117.5, C & & \\
\hline$C-2^{\prime}$ & $125.1, \mathrm{CH}$ & $5.07, \mathrm{t}(6.6)$ & & $160.0, \mathrm{C}$ & & \\
\hline$C-3^{\prime}$ & $130.5, \mathrm{C}$ & & & $128.2, \mathrm{CH}$ & $8.02, \mathrm{~d}(8.4)$ & $2^{\prime}, 4^{\prime}$ \\
\hline C-4' & $25.8, \mathrm{CH}_{3}$ & $1.60, \mathrm{~s}$ & $2^{\prime}, 3^{\prime}, 5^{\prime}$ & $157.1, \mathrm{C}$ & & \\
\hline$C-5^{\prime}$ & 17.9, $\mathrm{CH}_{3}$ & $1.77, \mathrm{~s}$ & $2^{\prime}, 3^{\prime}, 4^{\prime}$ & $116.8, \mathrm{CH}$ & $6.92, \mathrm{dd}(2.4,8.4)$ & $1^{\prime}$ \\
\hline C-6' & & & & 103.3, CH & $6.82, \mathrm{~d}(2.4)$ & $2^{\prime}$ \\
\hline C-1" & & & & $23.5, \mathrm{CH}_{2}$ & $3.38, \mathrm{~d}(6.6)$ & $5,6,7,2^{\prime \prime}, 3^{\prime \prime}$ \\
\hline C-2" & & & & $125.2, \mathrm{CH}$ & $5.14, \mathrm{t}(6.6)$ & \\
\hline C-3" & & & & $130.9, \mathrm{C}$ & & \\
\hline C-4" & & & & 17.7, $\mathrm{CH}_{3}$ & $1.73, \mathrm{~s}$ & $2^{\prime \prime}, 3^{\prime \prime}$ \\
\hline C-5" & & & & $25.7, \mathrm{CH}_{3}$ & $1.64, \mathrm{~s}$ & 2", 3" \\
\hline $5-\mathrm{OCH}_{3}$ & & & & $61.3, \mathrm{CH}_{3}$ & $3.78, \mathrm{~s}$ & 5 \\
\hline 7- $-\mathrm{OCH}_{3}$ & & & & $55.9, \mathrm{CH}_{3}$ & $3.43, \mathrm{~s}$ & 7 \\
\hline
\end{tabular}

${ }^{a} \mathrm{HMBC}$ correlations, optimized for $5 \mathrm{~Hz}$, are from proton(s) stated to the optimized carbon. 
The ${ }^{13} \mathrm{C}-\mathrm{NMR}$ spectrum showed five carbon signals ascribable to a prenyl group $\left[\delta_{\mathrm{C}} 17.9,25.8\right.$ (dimethyl at C-3'), $\delta_{\mathrm{C}} 23.3\left(\mathrm{C}-1^{\prime}\right), \delta_{\mathrm{C}} 125.1\left(\mathrm{C}-2^{\prime}\right), \delta_{\mathrm{C}} 130.5\left(\mathrm{C}-3^{\prime}\right)$ ], in addition to fifteen carbon signals assignable to the coumestan skeleton (see Table 1). Four carbon signals at $\delta_{\mathrm{C}} 104.1(\mathrm{C}-11 \mathrm{~b}), \delta_{\mathrm{C}} 113.9$ $(\mathrm{C}-2), \delta_{\mathrm{C}} 156.4(\mathrm{C}-4 \mathrm{a})$, and $\delta_{\mathrm{C}} 158.5(\mathrm{C}-3)$ among the $s p^{2}$ carbon signals are correlated with the aromatic proton at $\delta_{\mathrm{H}} 6.25(\mathrm{H}-4)$ in the ${ }^{1} \mathrm{H}$-detected multiple bond correlation (HMBC) spectrum (Figure 3). On the other hand, correlations of the methylene proton signal at $\delta_{\mathrm{H}} 3.12\left(\mathrm{H}-1^{\prime}\right)$ with the carbon signals at $\delta_{\mathrm{C}} 113.9(\mathrm{C}-2), \delta_{\mathrm{C}} 158.5(\mathrm{C}-3)$, and $\delta_{\mathrm{C}} 160.4(\mathrm{C}-1)$, along with the correlations with the allylic carbon signals at $\delta_{\mathrm{C}} 125.1\left(\mathrm{C}-2^{\prime}\right)$ and $\delta_{\mathrm{C}} 130.5\left(\mathrm{C}-3^{\prime}\right)$, were also observed in the HMBC spectrum. These correlations are coincided with the location of the prenyl group at C-2.

The substitution pattern of the hydroxyl and prenyl groups on the coumestan skeleton was further confirmed by chemical evidence. Compound A (31) was methylated (see Experimental Section) to afford the methyl derivative 31a (Figure 2), which was identical with the compound obtained by methylation of the known compound glycyrol (15). The structure of demethylglycyrol (31) for compound A was thus established.

Compound B (32, (Figure 4) was also obtained as a pale-yellow microcrystalline powder. Its HR-FAB-MS data (Found $383.1448[\mathrm{M}+\mathrm{H}]^{+}$, Calcd 383.1495) indicated that this compound has a molecular formula $\mathrm{C}_{22} \mathrm{H}_{22} \mathrm{O}_{6}$. The UV spectrum of 32 with the absorption maxima at $258(\log \varepsilon, 4.08)$ $291 \mathrm{sh}$, and $340 \mathrm{~nm}(\log \varepsilon, 3.93)$ suggested that it has an isoflavone skeleton as the chromophore. The ${ }^{1} \mathrm{H}-\mathrm{NMR}$ spectrum showed two one-proton singlets at $\delta_{\mathrm{H}} 7.97(\mathrm{H}-2)$ and $\delta_{\mathrm{H}} 6.38(\mathrm{H}-8)$, and three protons forming an $\mathrm{ABX}$ system at $\delta_{\mathrm{H}} 6.91\left(1 \mathrm{H}, \mathrm{d}, J=2.4 \mathrm{H}_{\mathrm{Z}}, \mathrm{H}-3^{\prime}\right), \delta_{\mathrm{H}} 6.99(1 \mathrm{H}, \mathrm{dd}, J=2.4,8.4 \mathrm{~Hz}$, $\left.\mathrm{H}^{-} 5^{\prime}\right)$, and $\delta_{\mathrm{H}} 8.02\left(1 \mathrm{H}, \mathrm{d}, J=8.4 \mathrm{~Hz}, \mathrm{H}-6^{\prime}\right)$ in the aromatic-proton region, corresponding to the isoflavone skeleton. The presence of the prenyl group was also indicated by a set of aliphatic protons at $\delta_{\mathrm{H}} 1.60,1.69\left(3 \mathrm{H}\right.$ each, s, dimethyl at C-3"), $\delta_{\mathrm{H}} 3.21\left(2 \mathrm{H}, \mathrm{d}, J=6.6 \mathrm{~Hz}, \mathrm{H}-1^{\prime \prime}\right)$, and $\delta_{\mathrm{H}} 5.14(1 \mathrm{H}, \mathrm{t}$, $\left.J=6.6 \mathrm{~Hz}, \mathrm{H}-2^{\prime \prime}\right)$. The presence of the two methoxyl groups was shown by the signals at $\delta_{\mathrm{H}} 3.40$ and $\delta_{\mathrm{H}} 3.76\left(3 \mathrm{H}\right.$ each, s). This ${ }^{1} \mathrm{H}$ signal pattern for compound B was closely similar to that of licoricone (28), suggesting a structure isomeric to 32. The ${ }^{13} \mathrm{C}-\mathrm{NMR}$ spectrum (in $\mathrm{CD}_{3} \mathrm{OD}$ ) of compound (32), however, was discriminable from that of 28. Compound $\mathrm{B}(\mathbf{3 2})$ showed the ${ }^{13} \mathrm{C}$ signals of the isoflavone skeleton $\left[\delta_{\mathrm{C}} 96.4(\mathrm{C}-8), \delta_{\mathrm{C}} 103.3\left(\mathrm{C}-3^{\prime}\right), \delta_{\mathrm{C}} 106.5(\mathrm{C}-4 \mathrm{a}), \delta_{\mathrm{C}} 115.6(\mathrm{C}-6), \delta_{\mathrm{C}} 116.8\left(\mathrm{C}-5^{\prime}\right), \delta_{\mathrm{C}}\right.$ $117.5\left(\mathrm{C}^{\prime} 1^{\prime}\right), \delta_{\mathrm{C}} 119.9(\mathrm{C}-3), \delta_{\mathrm{C}} 128.2\left(\mathrm{C}^{\prime} 6^{\prime}\right), \delta_{\mathrm{C}} 156.7(\mathrm{C}-8 \mathrm{a}), \delta_{\mathrm{C}} 157.1\left(\mathrm{C}-4{ }^{\prime}\right), \delta_{\mathrm{C}} 159.2(\mathrm{C}-5)$, $\delta_{\mathrm{C}} 160.0\left(\mathrm{C}-2^{\prime}\right), \delta_{\mathrm{C}} 160.4(\mathrm{C}-7), \delta_{\mathrm{C}} 170.1(\mathrm{C}-2), \delta_{\mathrm{C}} 178.8(\mathrm{C}-4)$ (see Table 1)], in addition to the prenyl [ $\delta_{\mathrm{C}} 17.7,25.4$ (dimethyl at $\left.\delta_{\mathrm{C}} \mathrm{C}-3 "\right) \delta_{\mathrm{C}} 23.5$ (C-1"), $\delta_{\mathrm{C}} 125.2$ (C-2"), $\delta_{\mathrm{C}} 130.9$ (C-3")] and methoxyl groups $\left(\delta_{\mathrm{C}} 55.9\right.$ and $\left.\delta_{\mathrm{C}} 61.3\right)$. Among the isoflavone skeleton signals of compound $\mathrm{B}(32)$, the chemical shift of $\mathrm{C}-2\left(\delta_{\mathrm{C}}\right.$ 170.1) showed a large difference from the corresponding carbon signal $\left(\delta_{\mathrm{C}}\right.$ 157.9) of licoricone (28) [39]. The assignment of C-2 in 32 was supported by the HMBC correlations of $\mathrm{H}-2$ signal $\left(\delta_{\mathrm{H}} 7.95\right)$ with carbon signals of C-3 $\left(\delta_{\mathrm{C}} 119.9\right), \mathrm{C}-4\left(\delta_{\mathrm{C}} 178.8\right)$, and C-1' $\left(\delta_{\mathrm{C}} 117.5\right)$, and correlations of $\mathrm{H}-5$ ' signal $\left(\delta_{\mathrm{H}} 6.92\right)$ with carbon signals of C-1' $\left(\delta_{\mathrm{C}} 117.5\right)$. The HMBC spectrum also showed correlations of H-8 signal $\left(\delta_{\mathrm{H}} 6.34\right)$ with carbon signals of C-4a $\left(\delta_{\mathrm{C}} 106.5\right), \mathrm{C}-6\left(\delta_{\mathrm{C}} 115.6\right), \mathrm{C}-8 \mathrm{a}\left(\delta_{\mathrm{C}} 156.7\right)$, and C-7 $\left(\delta_{\mathrm{C}} 160.4\right)$, and that of H-1" $\left(\delta_{\mathrm{H}} 3.38\right)$ with those of C-6 $\left(\delta_{\mathrm{C}} 115.6\right), \mathrm{C}-2$ " $\left(\delta_{\mathrm{C}} 125.2\right), \mathrm{C}-5\left(\delta_{\mathrm{C}} 159.2\right)$, and C-7 $\left(\delta_{\mathrm{C}} 160.4\right)$, substantiating the location C-6 for the prenyl group. The HMBC correlations (Figure 4) for the methoxyl groups $\left[\delta_{\mathrm{H}} 3.78\right.$ with $\mathrm{C}-5$ $\left(\delta_{\mathrm{C}} 61.3\right)$, and $\delta_{\mathrm{H}} 3.43$ with C-7 $\left.\left(\delta_{\mathrm{C}} 55.9\right)\right]$ emphasized their locations at C-5 and C-7. The structure of 5,7-di-O-methylluteone (33) was thus assigned for compound B. 
Figure 4. HMBC correlations observed for compound B (5,7-di-O-methylluteone, 32).

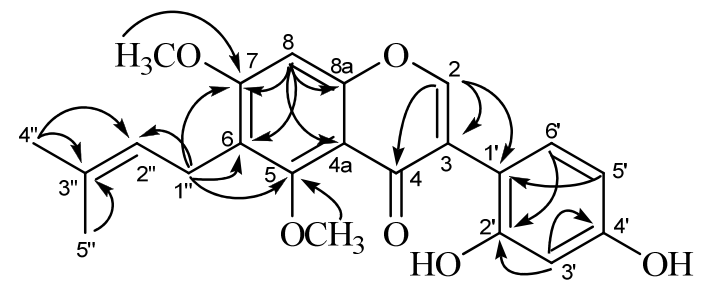

\subsection{Antibacterial Effects of Licorice Phenolics on VRE}

E. faecium FN-1 and E. faecalis NCTC 12201 strains were used in this study. The antibacterial effects of the licorice phenolics on the VRE strains were estimated using the liquid dilution method. Although except for linezolid almost all of the tested antibacterial standard drugs showed high minimum inhibitory concentration (MIC) values against at least one of the two used strains as shown in Table 2, among the licorice phenolics examined in this study, a 2-arylcoumarin, gancaonin I (17) showed potent antibacterial effects against E. faecium (MIC of $8 \mu \mathrm{g} / \mathrm{mL}$ ), and E. faecalis (MIC of $16 \mu \mathrm{g} / \mathrm{mL}$ ). Additionally, two 3-arylcoumarins, licoarylcoumarin (9) and glycycoumarin (26) showed low MIC values $(16 \mu \mathrm{g} / \mathrm{mL})$ for E. faecium and E. faecalis. An isoflavone semilicoisoflavone B (14), and an isoflavan glyasperin D (29) showed potent $(16 \mu \mathrm{g} / \mathrm{mL})$ to moderate MIC (32 $\mu \mathrm{g} / \mathrm{mL})$ for E. faecium. Flavonols, flavanones, and chalcones showed no or weak $(\sim 128 \mu \mathrm{g} / \mathrm{mL})$ antibacterial effects. Noticeable that the compounds with two or three phenolic hydroxyl groups accompanied by a prenyl group showed potent anti-VRE effects relative to those of the other structural features. Since coumestans such as isoglycyrol (18) and demethlglycyrol (31) showed weak antibacterial effects relative to those of 3-arylcoumarins, the structural rigidity may cause decrease of the effects.

Table 2. Antibacterial effects of licorice phenolics on enterococci shown by their minimum inhibitory concentrations $(\mu \mathrm{g} / \mathrm{mL})$.

\begin{tabular}{lcc}
\hline \multirow{2}{*}{ Compounds } & \multicolumn{2}{c}{ Bacterial Strains } \\
\cline { 2 - 3 } & Enterococcus faecium FN-1 & Enterococcus faecalis NCTC12201 \\
\hline Flavonols and related compounds & $>128$ & \\
Kaempferol-3-O-methyl ether (5) & $>128$ & $>128$ \\
Kaempferol (6) & $>128$ & 128 \\
Isolicoflavonol (7) & & \\
Flavanones & $>128$ & $>128$ \\
6"-O-Acetylliquiritin (11) & $>128$ & 128 \\
Liquiritin (12) & $>128$ & $>128$ \\
Liquiritigenin (19) & & \\
Chalcone & $>128$ & $>128$ \\
Isoliquiritin (23) & & \\
Isoflavones and Isoflavans & $>128$ & 128 \\
Allolicoisoflavone B (2) & $>128$ & $>128$ \\
Formononetin (10) & 32 & 64 \\
Semilicoisoflavone B (14) & 64 & 128 \\
5,7-Di-O-Methylluteone (32) & 64 & 128 \\
Gancaonin G (20) & & \\
\hline
\end{tabular}


Table 2. Cont.

\begin{tabular}{|c|c|c|}
\hline \multirow{2}{*}{ Compounds } & \multicolumn{2}{|c|}{ Bacterial Strains } \\
\hline & Enterococcus faecium $\mathrm{FN}-1$ & Enterococcus faecalis NCTC12201 \\
\hline 6,8-Diprenylorobol (22) & 128 & 128 \\
\hline Glicoricone (25) & $>128$ & $>128$ \\
\hline Licoricone (28) & 128 & $>128$ \\
\hline Glyasperin D (29) & 32 & 64 \\
\hline \multicolumn{3}{|l|}{ 3-Arylcoumarins } \\
\hline Isoglycycoumarin (8) & 64 & $>128$ \\
\hline Licoarylcoumarin $(9)$ & 16 & 16 \\
\hline Glycyrin (16) & 16 & 32 \\
\hline Glycycoumarin (26) & 16 & 16 \\
\hline \multicolumn{3}{|l|}{ Coumestans } \\
\hline Glycyrol (15) & $>128$ & $>128$ \\
\hline Isoglycyrol (18) & 32 & 64 \\
\hline Demethlglycyrol (31) & 64 & 64 \\
\hline \multicolumn{3}{|l|}{ 2-Arylcoumarones } \\
\hline Gancaonin I (17) & 8 & 16 \\
\hline Licocoumarone (27) & 32 & 32 \\
\hline \multicolumn{3}{|l|}{ Others } \\
\hline$p$-Hydroxybenzoic acid (13) & $>128$ & 128 \\
\hline \multicolumn{3}{|l|}{ Standard antibacterial drugs } \\
\hline Erythromycin & $>1024$ & $>1024$ \\
\hline Norfloxacin & $>128$ & 4 \\
\hline Vancomycin & $>100$ & $>100$ \\
\hline Linezolid & 2.5 & 2.5 \\
\hline Imipenem & $>64$ & 2 \\
\hline Tetracycline & 64 & 128 \\
\hline Oxacillin & $>1024$ & 256 \\
\hline Gentamicin & $>1024$ & $>1024$ \\
\hline
\end{tabular}

\section{Experimental}

\subsection{General}

UV spectra were recorded on a JASCO V-530 spectrometer. ESI-MS measurements were performed on an API-4000 instrument. HR-FAB-MS measurements were conducted on a JEOL JMS-700 MStation with a mixture of $m$-nitrobenzyl alcohol and dithiothreitol as the matrix. ${ }^{1} \mathrm{H}-$ and ${ }^{13} \mathrm{C}-\mathrm{NMR}$ spectra were recorded on an Agilent INOVA 600AS instrument $\left(600 \mathrm{MHz}\right.$ for ${ }^{1} \mathrm{H}$, and $151 \mathrm{MHz}$ for ${ }^{13} \mathrm{C}$ ), and the chemical shifts were given in $\delta(\mathrm{ppm})$ downfield from tetramethylsilane, based on those of the solvent signals $\left[\delta_{\mathrm{H}} 2.04\right.$ and $\delta_{\mathrm{C}} 29.8$ for $\left(\mathrm{CD}_{3}\right)_{2} \mathrm{CO}$, and $\delta_{\mathrm{H}} 3.30$ and $\delta_{\mathrm{C}} 49.8$ for $\left.\mathrm{CD}_{3} \mathrm{OD}\right)$. Optical rotations were measured on a JASCO DIP-1000 digital polarimeter. Normal-phase analytical HPLC was performed on an YMC SIL-003 (4.6 mm i.d. $\times 250 \mathrm{~mm}$ ) column (YMC, Kyoto, Japan) with $n$-hexane- $\mathrm{CH}_{3} \mathrm{OH}$-tetrahydrofuran-formic acid $(55: 33: 11: 1, v / v)$ containing oxalic acid $(450 \mathrm{mg} / \mathrm{L})$ as the eluent at the ambient temperature. Flow rate was set at $1.5 \mathrm{~mL} / \mathrm{min}$. Reversed-phase 
analytical HPLC was conducted on an YMC ODS-A $302(4.6 \mathrm{~mm}$ i.d. $\times 250 \mathrm{~mm})$ column with $10 \mathrm{mM}$ $\mathrm{H}_{3} \mathrm{PO}_{4}-10 \mathrm{mM} \mathrm{KH}_{2} \mathrm{PO}_{4}-\mathrm{CH}_{3} \mathrm{CN}-\mathrm{CH}_{3} \mathrm{COOH}(35: 35: 28: 2, v / v)$ as the eluent at $40{ }^{\circ} \mathrm{C}$ Flow rate was set at $1.0 \mathrm{~mL} / \mathrm{min}$. Preparative HPLC was performed on an YMC ODS-A324 (10 mm i.d. $\times 300 \mathrm{~mm})$ column with $\mathrm{H}_{2} \mathrm{O}-\mathrm{CH}_{3} \mathrm{CN}-\mathrm{CH}_{3} \mathrm{COOH}(45: 50: 5, v / v)$ as the eluent. Detection for HPLC was effected with UV absorption at $280 \mathrm{~nm}$. Silica gel (YMC), Toyopearl HW-40 (Coarse grade) (TOSOH, Tokyo, Japan), YMC-gel ODS-A (S, $75 \mu \mathrm{m}$ ) (YMC), and MCI-gel CHP-20P (Mitsubishi Chemical, Tokyo, Japan) were used for column chromatography. Sep-Pak C18 short cartridges (Waters, Milford, PA, USA) were also used for purification of compounds.

\subsection{Plant Material}

The crude drug used in this study is Tohoku Licorice (root and stolon of Glycyrrhiza uralensis), purchased from Tochimoto-tenkai-do (Osaka, Japan) (Lot No. 002009037), and the specimen GU-07112011(NEL) was kept at the Medicinal Plant Garden, Okayama University Graduate School of Medicine, Dentistry and Pharmaceutical Sciences.

\subsection{Extraction and Isolation}

Tohoku Licorice $(1.0 \mathrm{~kg})$ was pulverized and defatted with $n$-hexane $(3 \mathrm{~L} \times 2)$, and then with ethyl acetate $(3 \mathrm{~L} \times 2)$. A part $(5 \mathrm{~g})$ of the ethyl acetate extract $(46.4 \mathrm{~g})$ was subjected to the countercurrent distribution $(n=4, r=4)$ with the solvent system $\mathrm{CHCl}_{3}-\mathrm{CH}_{3} \mathrm{OH}-\mathrm{H}_{2} \mathrm{O}(7: 13: 8, v / v)$, to give 8 fractions [Lower phase (L1-L4) and upper phase (U1-U4) fractions with the following order of the polarity, L1 $(3.93 \mathrm{~g})<\mathrm{L} 2(0.53 \mathrm{~g})<\mathrm{L} 3(101 \mathrm{mg})<\mathrm{L} 4(69 \mathrm{mg})<\mathrm{U} 4(50 \mathrm{mg})<\mathrm{U} 3(59 \mathrm{mg})<\mathrm{U} 2$ $(71 \mathrm{mg})<\mathrm{U} 1(51 \mathrm{mg})]$. The $\mathrm{L} 1$ fraction was subjected to column chromatography on silica gel $(3.0 \mathrm{~cm}$ i.d. $\times 30 \mathrm{~cm}$ ) with increasing concentrations of $\mathrm{CH}_{3} \mathrm{OH}$ in $\mathrm{CHCl}_{3}$, to give 58 fractions. Combined fractions 10-13 (0.47 g) were subjected to column chromatography on ODS-gel $(1.1$ i.d. $\times 42 \mathrm{~cm})$ with increasing concentrations of $\mathrm{CH}_{3} \mathrm{OH}$ in $\mathrm{H}_{2} \mathrm{O}$, and the eluate with $20 \% \mathrm{CH}_{3} \mathrm{OH}$ in $\mathrm{H}_{2} \mathrm{O}(155 \mathrm{mg})$ was further separated by column chromatography on MCI-gel CHP-20P $(1.1$ i.d. $\times 40 \mathrm{~cm})$ with increasing concentrations of $\mathrm{CH}_{3} \mathrm{OH}$ in $\mathrm{H}_{2} \mathrm{O}$, to give licoricidin (1) (10.2 mg), allolicoisoflavone $\mathrm{B}$ (2) (4.5 mg), and 3'-( $\gamma, \gamma$-dimethylallyl)-kievitone (3) $\left(3.4 \mathrm{mg}\right.$ ). The eluate with $25 \% \mathrm{CH}_{3} \mathrm{OH}$ in $\mathrm{H}_{2} \mathrm{O}(43 \mathrm{mg})$ from the ODS-gel column was purified by preparative TLC on silica gel with $\mathrm{CHCl}_{3}-\mathrm{CH}_{3} \mathrm{OH}$ (9:1) to give isolicoflavonol (7) (3.1 mg), isoglycycoumarin (8) (2.5 mg), and licoarylcoumarin (9) (5.8 $\mathrm{mg})$. The L2 fraction from the countercurrent distribution was subjected to column chromatography on silica gel ( 3.0 i.d. $\times 30 \mathrm{~cm}$ ) with increasing concentrations of $\mathrm{CH}_{3} \mathrm{OH}$ in $\mathrm{CHCl}_{3}$, to give 25 fractions. Combined fractions 7-10 (0.18 g) were chromatographed on an ODS-gel column $(1.1$ i.d. $\times 42 \mathrm{~cm})$ with increasing concentrations of $\mathrm{CH}_{3} \mathrm{OH}$ in $\mathrm{H}_{2} \mathrm{O}$, and the eluate with $20 \% \mathrm{CH}_{3} \mathrm{OH}$ in $\mathrm{H}_{2} \mathrm{O}(66 \mathrm{mg})$ was further chromatographed on an MCI-gel CHP-20P column $(1.1$ i.d. $\times 40 \mathrm{~cm})$ with increasing concentrations of $\mathrm{CH}_{3} \mathrm{OH}$ in $\mathrm{H}_{2} \mathrm{O}$, to give 7-O-methylluteone (4) (1.9 mg), kaempferol 3-O-methyl ether (5) (3.1 mg), and kaempferol (6) $(6.8 \mathrm{mg})$. The eluate with $25 \% \mathrm{CH}_{3} \mathrm{OH}$ in $\mathrm{H}_{2} \mathrm{O}(20 \mathrm{mg})$ from the ODS-gel column was purified by preparative TLC on silica gel with $\mathrm{CHCl}_{3}-\mathrm{CH}_{3} \mathrm{OH}$ (9:1), to give formononetin (10) $(1.3 \mathrm{mg})$. The eluate with $30 \% \mathrm{CH}_{3} \mathrm{OH}$ in $\mathrm{H}_{2} \mathrm{O}(10 \mathrm{mg})$ from the ODS-gel column was purified by preparative HPLC to give 6"-O-acetylliquiritin (11) $(3.8 \mathrm{mg})$. 
Separately, the ethyl acetate extract $(40 \mathrm{~g})$ from Tohoku Licorice was subjected to column chromatography on ODS-gel $(2.2$ i.d. $\times 75 \mathrm{~cm})$ with increasing concentrations of $\mathrm{CH}_{3} \mathrm{OH}$ in $\mathrm{H}_{2} \mathrm{O}$ and then with increasing concentrations of $\mathrm{CHCl}_{3}$ in $\mathrm{CH}_{3} \mathrm{OH}$. The eluate with $10 \% \mathrm{CHCl}_{3}$ in $\mathrm{CH}_{3} \mathrm{OH}(4.1 \mathrm{~g})$ was subjected to column chromatography on MCI-gel CHP-20P $(2.2$ i.d. $\times 45 \mathrm{~cm})$ with increasing concentrations of $\mathrm{CH}_{3} \mathrm{OH}$ in $\mathrm{H}_{2} \mathrm{O}$, and the eluate with $15 \% \mathrm{CH}_{3} \mathrm{OH}$ in $\mathrm{H}_{2} \mathrm{O}(86 \mathrm{mg})$ was purified by preparative HPLC, to give liquiritin (12) $(8.3 \mathrm{mg})$. The eluate with $30 \% \mathrm{CH}_{3} \mathrm{OH}$ in $\mathrm{H}_{2} \mathrm{O}(53 \mathrm{mg})$ was purified by preparative TLC on silica gel with $\mathrm{CHCl}_{3}-\mathrm{CH}_{3} \mathrm{OH}$, to give $p$-hydroxybenzoic acid (13) $(6.9 \mathrm{mg})$ and semilicoisoflavone $\mathrm{B}(\mathbf{1 4})(2.0 \mathrm{mg})$. The eluate with $50 \% \mathrm{CHCl}_{3}$ in $\mathrm{CH}_{3} \mathrm{OH}(3.6 \mathrm{~g})$ was subjected to column chromatography on MCI-gel CHP-20P $(2.2$ i.d. $\times 45 \mathrm{~cm})$ with increasing concentrations of $\mathrm{CH}_{3} \mathrm{OH}$ in $\mathrm{H}_{2} \mathrm{O}$, and fractions 85 (48 mg), 94 (42 mg), 96 (40 mg), 137 (22 mg), 236-237 (19 mg), and 343-347 (59 mg) were respectively purified by preparative HPLC to give glycyrol (15) (4.1 mg), glycyrin (16) (15.4 mg) (from fraction 85), compound B (5,7-di-O-Methylluteone 32) (3.5 mg), gancaonin I (17) $(5.9 \mathrm{mg})$, isoglycyrol (18) (4.2 mg) (from fraction 94), liquiritigenin (19) (8.5 mg), gancaonin $\mathrm{G}$ (20) (3.1 mg), 3-(p-hydroxyphenyl)-7methoxycoumarin (21) (1.2 mg), 6,8-diprenylorobol (22) (4.2 $\mathrm{mg}$ ) (from fraction 96), isoliquiritin (23) (2.3 mg), 8-( $\gamma, \gamma$-dimethylallyl)-wighteone (24) (1.9 $\mathrm{mg})$ (from fraction 137), compound A (Demethylglycyrol, 31) (1.8 mg), glicoricone (25) (3.9 mg) (from combined fractions 236-237), glycycoumarin (26) (5.3 mg), licocoumarone (27) (7.9 mg), licoricone (28) (2.1 mg), glyasperin D (29) (3.5 mg) and isoangustone A (30) (4.5 mg) (from combined fractions 343-347).

\subsection{Spectral Data}

Compound A (demethylglycyrol, 31): A pale-yellow, microcrystalline powder $(\mathrm{MeOH}) ; \mathrm{mp} 265^{\circ} \mathrm{C}$; UV $(\mathrm{MeOH}) \lambda_{\max }(\log \varepsilon) 210$ (4.47), 259 (4.45), 345 (4.23) nm; ${ }^{1} \mathrm{H}-$ and ${ }^{13} \mathrm{C}-\mathrm{NMR}$ data see Table 1; ESIMS $m / z 353\left([\mathrm{M}+\mathrm{H}]^{+}\right)$; HR-FAB-MS $m / z 353.0990\left([\mathrm{M}+\mathrm{H}]^{+}\right)\left(\right.$Calcd. for $\left.\mathrm{C}_{20} \mathrm{H}_{17} \mathrm{O}_{6}, 353.1025\right)$.

Compound B (5,7-di-O-methylluteone, 32): A pale-yellow, microcrystalline solid (MeOH); mp $205{ }^{\circ} \mathrm{C}$; UV (MeOH) $\lambda_{\max }(\log \varepsilon) 210$ (4.15), 258 (4.08), 291 (sh), 340 (3.93) nm; ${ }^{1} \mathrm{H}-$ and ${ }^{13} \mathrm{C}-\mathrm{NMR}$ data see Table 1; ESI-MS $m / z 383\left([\mathrm{M}+\mathrm{H}]^{+}\right)$, HR-FAB-MS $m / z 383.1448\left([\mathrm{M}+\mathrm{H}]^{+}\right)(\mathrm{Calcd}$. for $\mathrm{C}_{22} \mathrm{H}_{23} \mathrm{O}_{6}, 383.1495$ ).

\subsection{Methylation of Compound A and Glycyrol}

Methylation of compound A (31) was carried out as shown in the literature [42]. Briefly, a solution of compound A $(1.5 \mathrm{mg})$ in $\mathrm{EtOH}$ was treated by TMS-diazomethane at room temperature $3 \mathrm{~h}$. The reaction mixture was concentrated under reduced pressure to a residue which was purified by TLC on silica gel $\left(\mathrm{CHCl}_{3}-\mathrm{MeOH}, 15: 1, v / v\right)$, to give three compounds: glycyrol $(0.5 \mathrm{mg})$, the monomethyl derivative of compound A (0.3 mg) (identified by $\left.{ }^{1} \mathrm{H}-\mathrm{NMR}\right)$, and the corresponding trimethyl derivative $(0.3 \mathrm{mg})\left(\mathbf{3 1}{ }^{\prime}\right.$, Figure 2$)$. Compound A-3Me $\left(31^{\prime}\right)$ : ${ }^{1} \mathrm{H}-\mathrm{NMR}$ (acetone- $\left.d_{6}\right): \delta_{\mathrm{H}} 1.66$ and $\delta_{\mathrm{H}}$ $1.81($ each $3 \mathrm{H}, \mathrm{s},-\mathrm{CH} 3 \times 3), \delta_{\mathrm{H}} 3.44(2 \mathrm{H}, \mathrm{d}, J=7 \mathrm{~Hz}, \mathrm{H}-1 "), \delta_{\mathrm{H}} 4.00,4.01,4.02\left(\right.$ each $\left.3 \mathrm{H}, \mathrm{s},-\mathrm{OCH}_{3} \times 3\right)$, $\delta_{\mathrm{H}} 5.22\left(1 \mathrm{H}, \mathrm{t}, J=7 \mathrm{~Hz}, \mathrm{H}-2^{\prime \prime}\right), \delta_{\mathrm{H}} 6.95(1 \mathrm{H}, \mathrm{s}, \mathrm{H}-8), \delta_{\mathrm{H}} 7.05\left(1 \mathrm{H}, \mathrm{dd}, J=2,8 \mathrm{H}_{\mathrm{Z}}, \mathrm{H}-5^{\prime}\right), \delta_{\mathrm{H}} 7.23(1 \mathrm{H}$, $\left.\mathrm{d}, J=2 \mathrm{~Hz}, \mathrm{H}-3^{\prime}\right), \delta_{\mathrm{H}} 7.82\left(1 \mathrm{H}, \mathrm{d}, J=8 \mathrm{~Hz}, \mathrm{H}-6^{\prime}\right), \delta_{\mathrm{H}} 7.97(1 \mathrm{H}, \mathrm{s}, \mathrm{H}-2)$. This compound is identical with that obtained by analogous treatment of glycyrol (15). 


\subsection{Antibacterial Assay}

Estimation of antibacterial effects of licorice phenolics on vancomycin-resistant Enterococcus strains was carried out as has been described in the literature $[9,43,44]$. Enterococcus faecium FN-1 and E. faecalis NCTC 12201 used in this study were vancomycin resistant ones which were kindly provided by Dr. Y. Ike, Gunma University. The bacterial cells, pre-cultured in Mueller-Hinton broth at $37^{\circ} \mathrm{C}$ under aerobic condition, were incubated in the presence of compounds with the concentrations obtained by serial two-fold dilution at $37{ }^{\circ} \mathrm{C}$ without shaking in 96 -well plates in the same broth for $24 \mathrm{~h}$. The inocula were adjusted to yield a final cell density of about $10^{5} \mathrm{CFU}$. The standard antibacterial drugs erythromycin, norfloxacin, vancomycin, linezolid, imipenem, tetracycline, oxacillin and gentamycin were used as reference compounds for the tested strains Enterococcus faecium FN-1 and E. faecalis NCTC 12201 in the present study. The minimum inhibitory concentrations (MICs) were estimated as the lowest concentrations where the bacterial cells were not observed visually. The MIC values were determined based on triplicate experiments.

\section{Conclusions}

Previous reports have shown that phenolics from licorice are potent antibacterial against MRSA [11,45], and some of them showed suppressing effects on the oxacillin resistance of MRSA [11]. To discover bioactive natural compounds from natural source, Glycyrrhiza uralensis was investigated, affording a new coumestan 31 and an isoflavone 32, together with three known flavanols 5-7, three flavanones 11, 12 and 19, a chalcone 23, eight isoflavones 2, 10, 14, 20, 22, 25, 28 and 32, one isoflavan 29, four 3-arylcoumarins 8, 9, 16 and 26, three coumestans 15, 18 and 31, two 2-arylcoumarins 17 and 27 and $p$-hydroxybenzoic acid (13). Vancomycin-resistant Enterococci (VRE) is a serious drug-resistant bacteria, and just a few compounds such as linezolid, or a combination of quinupristin and dalfopristin have been used for treatments of diseases caused by them [12]. Therefore we have also investigated the effectiveness of the thirty two licorice phenolics isolated in this study on VRE, and we found that several compounds possesses moderate to potent antibacterial activity against VRE, and the 2-arylcoumarone gancaonin I (17) have the highest potency against the tested strains E. faecium (MIC of $8 \mu \mathrm{g} / \mathrm{mL}$ ), and E. faecalis (MIC of $16 \mu \mathrm{g} / \mathrm{mL}$ ), which is in agreement with the previously reported potent activity for a 2-arylcoumarin, gancaonin I (17) [15]. In addition to that, two 3-arylcoumarins, licoarylcoumarin (9) and glycycoumarin (26), also showed comparable antibacterial effects on E. faecalis $(16 \mu \mathrm{g} / \mathrm{mL})$. These findings could be useful in developing antibacterial agents from licorice and its various active phenolics. Besides the well-known traditional uses of licorice and the various reported biological effects [1-8], a recent study has added that several licorice phenolics exhibit higher tumor-specific cytotoxic effects [46]. However, further specific investigations on the safety of the pure licorice phenolics for human are awaited.

\section{Acknowledgments}

This study was supported in part by Drug Discovery Project for Intractable Infectious Diseases of Okayama University (IIDPO). The NMR instrument used is the property of Advanced Science Research Center, Okayama University. 


\section{Author Contributions}

The contributions of the respective authors are as follows: Eerdunbayaer performed isolation, identification, and structure elucidation of the constituents, and prepared the manuscript. M. A. A. Orabi contributed to checking and confirming all of the procedures of the isolation and structural identification, especially interpretation of the NMR spectra, and also to preparing the manuscript. H. Aoyama contributed to the MS measurements and interpretation of those spectra. T. Kuroda contributed to the antibacterial experiments. This study was performed based on the planning of T. Hatano, the corresponding author.

\section{Conflicts of Interest}

The authors declare no conflict of interest.

\section{References}

1. Isbrucker, R.A.; Burdock, G.A. Risk and safety assessment on the consumption of licorice root (Glycyrrhiza sp.), its extract and powder as a food ingredient, with emphasis on the pharmacology and toxicology of glycyrrhizin. Regul. Toxicol. Pharm. 2006, 46, 167-192.

2. Shen, X.-P.; Xiao, P.-G.; Liu, C.-X. Research and application of Radix Glycyrrhizae. Asian J. Pharmacodyn. Pharmacokin. 2007, 7, 181-200.

3. Asl, M.N.; Hosseinzadeh, H. Review of pharmacological effects of Glycyrrhiza sp. and its bioactive compounds. Phytother. Res. 2008, 22, 709-724.

4. Messier, C.; Epifano, F.; Genovese, S.; Grenier, D. Licorice and its potential beneficial effects in common oro-dental diseases. Oral Dis. 2012, 18, 32-39.

5. Villinski, J.R.; Bergeron, C.; Cannistra, J.C.; Gloer, J.B.; Coleman, C.M.; Ferreira, D.; Gafner, S. Pyrano-isoflavans from Glycyrrhiza uralensis with antibacterial activity against Streptococcus mutans and Porphyromonas gingivalis. J. Nat. Prod. 2014, doi:10.1021/np400788r.

6. Gafner, S.; Bergeron, C.; Villinski, J.R.; Godejohann, M.; Kessler, P.; Cardellina, J.H.; Grenier, D. Isoflavonoids and coumarins from Glycyrrhiza uralensis: Antibacterial activity against oral pathogens and conversion of isoflavans into isoflavan-quinones during purification. J. Nat. Prod. 2011, 74, 2514-2519.

7. He, J.; Chen, L.; Heber, D.; Shi, W.; Lu, Q.Y. Antibacterial Compounds from Glycyrrhiza uralensis. J. Nat. Prod. 2006, 69, 121-124.

8. Fukai, T.; Marumo, A.; Kaitou, K.; Kanda, T.; Terada, S.; Nomura, T. Anti- Helicobacter pylori flavonoids from licorice extract. Life Sci. 2002, 71, 1449-1463.

9. Otsuka, N.; Liu, M.-H.; Shiota, S.; Ogawa, W.; Kuroda, T.; Hatano, T.; Tsuchiya, T. Anti-methicillin resistant Staphylococcus aureus (MRSA) compounds isolated from Laurus nobilis. Biol. Pharm. Bull. 2008, 31, 1794-1797.

10. Hatano, T.; Kusuda, M.; Inada, K.; Ogawa, T.; Shiota, S.; Tsuchiya, T.; Yoshida, T. Effects of tannins and related polyphenols on methicillin-resistant Staphylococcus aureus. Phytochemistry 2005, 66, 2047-2055. 
11. Hatano, T.; Shintani, Y.; Aga, Y.; Shiota, S.; Tsuchiya, T.; Yoshida, T. Phenolic constituents of licorice. VIII. Structures of glicophenone and glicoisoflavanone, and effects of licorice phenolics on methicillin-resistant Staphylococcus aureus. Chem. Pharm. Bull. 2000, 48, 1286-1292.

12. McNeil, S.A.; Clark, N.M.; Chandrasekar, P.H.; Kauffman, C.A. Successful treatment of vancomycin-resistant Enterococcus faecium bacteremia with linezolid after failure of treatment with synercid (quinupristin/dalfopristin). Clin. Infect. Dis. 2000, 30, 403-404.

13. Irani, M.; Sarmadi, M.; Bernard, F. Leaves Antimicrobial activity of Glycyrrhiza glabra L. Iran J. Pharm. Res. 2010, 9, 425-428.

14. Badr, A.E.; Omar, N.; Badria, F.A. A laboratory evaluation of the antibacterial and cytotoxic effect of liquorice when used as root canal medicament. Int. Endod. J. 2011, 44, 51-58.

15. Fukai, T.; Oku, Y.; Hano, Y.; Terada, S. Antimicrobial activities of hydrophobic 2-Arylbenzofurans and an isoflavone against vancomycin-resistant Enterococci and methicillin-resistant Staphylococcus aureus. Planta Med. 2004, 70, 685-687.

16. Park, S.Y.; Lim, S.S.; Kim, J.K.; Kang, I.J.; Kim, J.S.; Lee, C.; Park, J.H.Y. Hexane-ethanol extract of Glycyrrhiza uralensis containing licoricidin inhibits the metastatic capacity of DU145 human prostate cancer cells. Br. J. Nutr. 2010, 104, 1272-1282.

17. Tahara, S.; Shibaki, S.; Ingham, J.L.; Mizutani, J. Further isoflavonoids from white lupin roots. Z. Naturforsch. C 1990, 45, 147-153.

18. O’Neill, M.J.; Adesanya, S.A.; Roberts, M.F.; Inez, R.P. Inducible isoflavonoids from the lima bean, Phaseolus lunatus. Phytochemistry 1986, 25, 1315-1322.

19. Tahara, S.; Ingham, J.L.; Mizutani, J. Metabolites of 7-O-methylluteone from Botrytis cinerea. Nippon Nogei Kagaku Kaishi 1989, 63, 999-1007.

20. Valesi, A.G.; Rodriguez, E.; Vander Velde, G.; Mabry, T.J. Methylated flavonols in Larrea cuneifolia. Phytochemistry 1972, 11, 2821-2826.

21. Xiao, Z.P.; Wu, H.K.; Wu, T.; Shi, H.; Hang, B.; Aisa, H.A. Kaempferol and quercetin flavonoids from Rosa rugosa. Chem. Nat. Compd. 2006, 42, 736-737.

22. Zheng, Z.P.; Cheng, K.W.; Chao, J.; Wu, J.; Wang, M. Tyrosinase inhibitors from paper mulberry (Broussonetia papyrifera). Food Chem. 2008, 106, 529-535.

23. Hatano, T.; Yasuhara, T.; Miyamoto, T.; Okuda, T. Anti-human immunodeficiency virus phenolics from licorice. Chem. Pharm. Bull. 1988, 36, 2286-2288.

24. Hatano, T.; Yasuhara, T.; Fukuda, T.; Noro, T.; Okuda, T. Phenolic constituents of licorice. II. Structures of licopyranocoumarin, licoarylcoumarin and glisoflavone, and glisoflavone, and inhibitory effects of licorice phenolics on xanthine oxidase. Chem. Pharm. Bull. 1989, 37, 3005-3009.

25. Chang, Y.C.; Nair, M.G.; Santell, R.C. Microwave-mediated synthesis of anticarcinogenic isoflavones from soybeans. J. Agric. Food Chem. 1994, 42, 1869-1871.

26. Shen, F.J.; Hu, J.F.; Yu, Y.C.; Xu, Z.D. Studies on chemical constituents of Glycyrrhiza uralensis Fisch. Gaodeng Xuexiao Huaxue Xuebao 1995, 16, 574-574.

27. Nakanishi, T.; Inada, A.; Kambayashi, K.; Yoneda, K. Flavonoid glycosides of the roots of Glycyrrhiza uralensis. Phytochemistry 1985, 24, 339-341.

28. Kiuchi, F.; Chen, X.; Tsuda, Y. Four new phenolic constituents from licorice (root of Glycyrrhiza sp.). Heterocycles 1990, 31, 629-636. 
29. Shul'ts, E.E.; Petrova, T.N.; Shakirov, M.M.; Chernyak, E.I.; Tolstikov, G.A. Flavonoids of roots of Glycyrrhiza uralensis growing in Siberia. Chem. Nat. Compd. 2000, 36, 362-368.

30. Nomura, T.; Fukai, T.; Wang, Q.H. Four new prenylated flavonoids from aerial parts of Glycyrrhiza uralensis. Heterocycles 1989, 29, 1761-1772.

31. Shiozawa, T.; Urata, S.; Kinoshita, T.; Saitoh, T. Revised structures of glycyrol and isoglycyrol, constituents of the root of Glycyrrhiza uralensis. Chem. Pharm. Bull. 1989, 37, 2239-2240.

32. Fukai, T.; Wang, Q.H.; Kitagawa, T.; Litaka, Y. Structures of six isoprenoids-substituted flavonoids, gancaonins F, G, R, I, glycyrol, and isoglycyrol from xibei licorice (Glycyrrhiza sp). Heterocycles 1989, 29, 1761-1772.

33. Krishnaswamy, N.R.; Seshadri, T.R.; Sharma, B.R. Study of partial demethylation of some polymethoxy-3-phenylcoumarins and preparation of some new members. Indian J. Chem. 1966, $4,120-126$.

34. Nkengfack, A.E.; Sanson, D.R.; Fomum, Z.T.; Tempesta, M.S. 8-Prenylluteone, a prenylated isoflavone from Erythrina eriotriocha. Phytochemistry 1989, 28, 2522-2526.

35. Farag, M.A.; Porzel, A.; Wessjohann, L.A. Comparative metabolite profiling and fingerprinting of medicinal licorice roots using a multiplex approach of GC-MS, LC-MS and 1D NMR techniques. Phytochemistry 2012, 76, 60-72.

36. Singhal, A.K.; Sharma, R.P.; Thyagarajan, G.; Herz, W.; Govindan, S.V. New prenylated isoflavones and a prenylated dihydroflavonol from Millettia pachycarpa. Phytochemistry 1980, 9, 929-934.

37. Hatano, T.; Fukuda, T.; Miyase, T.; Noro, T.; Okuda, T. Phenolic constituents of licorice. III. Structures of glicoricone and licofuranone, and inhibitory effects of licorice constituents on monoamine oxidase. Chem. Pharm. Bull. 1991, 39, 1238-1243.

38. Zhu, D.Y.; Song, G.Q.; Jian, F.X.; Chang, X.R.; Guo, W.B. Chemical constituents of Glycyrrhiza uralensis Fisch-Structures of isolicoflavonol and glycycoumarin. Ниахие Хиеbao 1984, 42, 1080-1084.

39. Kaneta, M.; Saitoh, T.; Iitaka, Y.; Shibata S. Chemical studies on the oriental plant drugs. XXXVI. Structure of licoricone, a new isoflavone from licorice root. Chem. Pharm. Bull. 1973, $21,1338-1341$.

40. Kwon, H.J.; Kim, H.H.; Ryu, Y.B.; Kim, J.H.; Jeong, H.J.; Lee, S.W.; Lee, W.S. In vitro anti-rotavirus activity of polyphenol compounds isolated from the roots of Glycyrrhiza uralensis. Bioor. Med. Chem. 2010, 18, 7668-7674.

41. Sil Lee, Y.; Ha Kim, S.; Kyu Kim, J.; Shin, H.K.; Kang, Y.H.; Park, Y.; Lim, S.S. Rapid identification and preparative isolation of antioxidant components in licorice. J. Sep. Sci. 2010, 33, 664-671.

42. Sasaki, H.; Kashiwada, Y.; Shibatav, H.; Takaishi, Y. Prenylated flavonoids from the roots of Desmodium caudatum and evaluation of their antifungal activity. Planta Med. 2012, 78, 1851-1856.

43. Nagoshi, C.; Shiota, S.; Kuroda, T.; Shiota, S.; Hatano, T.; Yoshida, T.; Kariyama, R.; Tsuchiya, T. Synergistic effect of [10]-gingerol and aminoglycosides against vancomycin-resistant Enterococci (VRE). Biol. Pharm. Bull. 2006, 29, 443-447. 
44. Hossion, A.M.; Zamami, Y.; Kandahary, R.K.; Tsuchiya, T.; Ogawa, W.; Iwado, A.; Sasaki, K. Quercetin diacylglycoside analogues showing dual inhibition of DNA gyrase and topoisomerase IV as novel antibacterial agents. J. Med. Chem. 2011, 54, 3686-3703.

45. Fukai, T.; Marumo, A.; Kaitou, K.; Kanda, T.; Terada, S.; Nomura, T. Antimicrobial activity of licorice flavonoids against methicillin-resistant Staphylococcus aureus. Fitoterapia 2002, 73, 536-539.

46. Ohno, H.; Araho, D.; Uesawa, Y.; Kagaya, H.; Ishihara, M.; Sakagami, H.; Yamamoto, M. Evaluation of cytotoxiciy and tumor-specificity of licorice flavonoids based on chemical structure. Anticancer Res. 2013, 33, 3061-3068.

Sample Availability: Samples of the compounds 1, 6, 9, 12, 13, 16, 19 and 27 are available from the authors.

(C) 2014 by the authors; licensee MDPI, Basel, Switzerland. This article is an open access article distributed under the terms and conditions of the Creative Commons Attribution license (http://creativecommons.org/licenses/by/3.0/). 